\title{
Comparative Analysis of Arbuscular Mycorrhizal Fungal Communities between Farmland and Woodland in the Black Soil Region of Northeast China
}

\author{
Wenying Yang ${ }^{1,2}$, Mengjie Zhang ${ }^{1,2}$, Fengbin Song ${ }^{1, *}$, Shengqun Liu ${ }^{1}$, Xiangnan Li ${ }^{1}$ and Xiancan Zhu ${ }^{3, *} \mathbb{D}$ \\ 1 Northeast Institute of Geography and Agroecology, Chinese Academy of Sciences, Changchun 130102, China; \\ yangwenying@iga.ac.cn (W.Y.); zhangmengjie@iga.ac.cn (M.Z.); lsq@iga.ac.cn (S.L.); \\ lixiangnan@iga.ac.cn (X.L.) \\ 2 University of Chinese Academy of Sciences, Beijing 101408, China \\ 3 Anhui Provincial Key Laboratory of the Conservation and Exploitation of Biological Resources, \\ Anhui Normal University, Wuhu 241000, China \\ * Correspondence: songfb@iga.ac.cn (F.S.); zhuxiancan@ahnu.edu.cn (X.Z.)
}

Citation: Yang, W.; Zhang, M.; Song, F.; Liu, S.; Li, X.; Zhu, X. Comparative Analysis of Arbuscular Mycorrhizal Fungal Communities between Farmland and Woodland in the Black Soil Region of Northeast China. Agriculture 2021, 11, 866. https:// doi.org/10.3390/agriculture11090866

Academic Editor: Cristina Abbate

Received: 20 August 2021

Accepted: 7 September 2021

Published: 10 September 2021

Publisher's Note: MDPI stays neutral with regard to jurisdictional claims in published maps and institutional affiliations.

Copyright: () 2021 by the authors. Licensee MDPI, Basel, Switzerland. This article is an open access article distributed under the terms and conditions of the Creative Commons Attribution (CC BY) license (https:// creativecommons.org/licenses/by/ $4.0 /)$.

\begin{abstract}
The black soil region of northeast China is a critical production base for commercial grain in China. Arbuscular mycorrhizal fungi (AMF) are widely present in terrestrial ecosystems and play a vital role in ecosystem stability. Here, we investigated the diversity and composition of AMF communities in farmland and woodland from 20 sites in the black soil region of northeast China using Illumina MiSeq sequencing. The sequences were classified into 1 phylum, 1 class, 4 orders, 8 families, and 11 genera. Glomerales and Paraglomerales were observed as the most abundant order in farmland and woodland, respectively, and also belonged to abundant orders of the black soil region in northeast China, accounting for more than $90 \%$ of the total. Furthermore, Paraglomus, Claroideoglomus, and Glomus were the most abundant genera. Canonical correspondence analysis demonstrated the effect of soil $\mathrm{pH}$, invertase, nitrogen, phosphorus, and soil organic carbon (SOC) contents on AMF community composition. Results from the correlation analysis revealed a reduction in AMF diversity with increases in SOC and phosphorus contents. These findings suggest AMF community composition varied with land use type (farmland and woodland), and provide a basis for protecting and utilizing AMF resources in the black soil region of northeast China.
\end{abstract}

Keywords: Glomeromycota; land use type; diversity; soil properties; black soils; Illumina Miseq

\section{Introduction}

Arbuscular mycorrhizal fungi (AMF) are ancient and ubiquitous soil microorganisms that form a mutually beneficial association with the majority of terrestrial plants [1]. In particular, AMF are symbiotic microorganisms that are not able to survive on their own and thus rely on living plants. In such symbiotic relationships, AMF help their host plants to absorb nutrients (e.g., nitrogen and phosphorus) while simultaneously obtaining the carbon source required from the hosts for their growth [2,3]. Moreover, AMF play an important role in ecosystems, by promoting plant growth, improving nitrogen and phosphorus acquisition, increasing plant stress resistance, stabilizing soil structure, and maintaining ecosystem balance $[4,5]$.

Black soils, also known as Mollisols (USA's soil taxonomy), are productive and fertile soils [6]. The black soil area in northeast China, one of the four main global regions of Mollisols, is generally distributed in the Heilongiiang, Jilin, Liaoning, and Inner Mongolia provinces/autonomous regions, with a total area of approximately $103 \times 10^{4} \mathrm{~km}^{2}$ [7]. Close to $7 \times 10^{4} \mathrm{~km}^{2}$ of the region is considered as a representative black soil region, based on the distribution area of 'black soil' in the Chinese soil classification system [7]. However, the long-term excessive cultivation and unreasonable management of this region has resulted in the serious degradation of the quality and quantity of the black soil, as well as alterations 
in the soil microbial community composition $[6,8]$. The reasonable utilization of black soil is beneficial in maintaining and improving soil fertility. With farmland and woodland as important land-use types in the black soil zone, their efficient utilization can indeed protect black soil. As AMF are a kind of soil microorganisms that are beneficial to the soil and plant, it is a need to improve our understanding of AMF community composition variations in farmland and woodland, and to determine how their corresponding differences across contrasting soil environments can be employed for the effective utilization and protection of black soil resources in northeast China.

Different land-use types have distinct influences on AMF community composition, due to variations in, for example, aboveground vegetation, underground organisms, and the underground soil environment [9,10]. Bainard et al. [11] demonstrated the ability of plant communities and soil properties to mediate the impact of agricultural land use on AMF communities in the Mixed Prairie ecoregion of the North American Great Plains. The impact of human disturbance intensities on land use types is a function of type, with low AMF diversities associated with high degrees of interference $[12,13]$. The diversity of AMF and its host plants are highly dependent on environmental conditions. Our previous studies revealed the diversity and composition of AMF communities in the cropland black soils of China and also made a comparison of the AMF community composition of five land-use types at a 100-m scale in the urban ecosystem [5,14]. However, the impact of land-use types on AMF community composition and diversity at the larger scale of the black soil region of northeast China remains largely unknown. Therefore, research on the AMF diversity in the black soil region of northeast China, with a focus on the exploration of the AMF community distribution under different land-use types, is of practical significance.

In the current study, we employed Illumina MiSeq sequencing to investigate the AMF diversity and community composition in farmland and woodland across 20 sites in the black soil region of northeast China. The objectives of the study were described as follows: (i) to examine and compare the diversity and community composition of AMF in farmland and woodland across the black soil region; and (ii) to explore the relationship between the edaphic factors and the community composition of AMF. We hypothesized AMF to exhibit different community characteristics across land-use types, which may be attributed to variations in soil properties.

\section{Materials and Methods}

\subsection{Sites}

Ten locations within the black soil region of northeast China, from Heilongiiang Province to Liaoning Province $\left(43^{\circ} 5^{\prime} \mathrm{N}-48^{\circ} 40^{\prime} \mathrm{N}, 124^{\circ} 20^{\prime} \mathrm{E}-126^{\circ} 29^{\prime} \mathrm{E}\right)$, were selected as the study sites (Figure 1).Adjacent farmland and woodland were selected as sample sites in the same location. Sampling took place between 16-19 September 2018. The study sites are part of a north temperate continental monsoon climate, with a mean annual temperature of $-2.5-5.6^{\circ} \mathrm{C}$ and average annual rainfall of $400-700 \mathrm{~mm}$. Soil samples from maize farmland and poplar woodland were collected at each site. Maize (Zea mays L.) farmland was selected due to its dominance among farming crops in northeast China, while the poplar (Populus L.) woodland is a general border tree in northern China. Four soil cores $(5.5 \mathrm{~cm}$ in diameter and $20 \mathrm{~cm}$ in depth) were collected randomly at each site within an area of approximately $100 \mathrm{~m}^{2}$ and regarded as four replicates. The samples were sieved through a $2 \mathrm{~mm}$ sieve to remove roots and other debris, homogenized and then divided into two groups, one of which was collected in a $5 \mathrm{~mL}$ centrifuge tube, frozen by liquid nitrogen, and transported to the laboratory to be stored at $-80^{\circ} \mathrm{C}$ for molecular analysis. The remaining soils were collected in the self-sealed bag and then air-dried for soil property measurements. There were 78 samples (two samples were discarded due to missing data)were analyzed in total. 


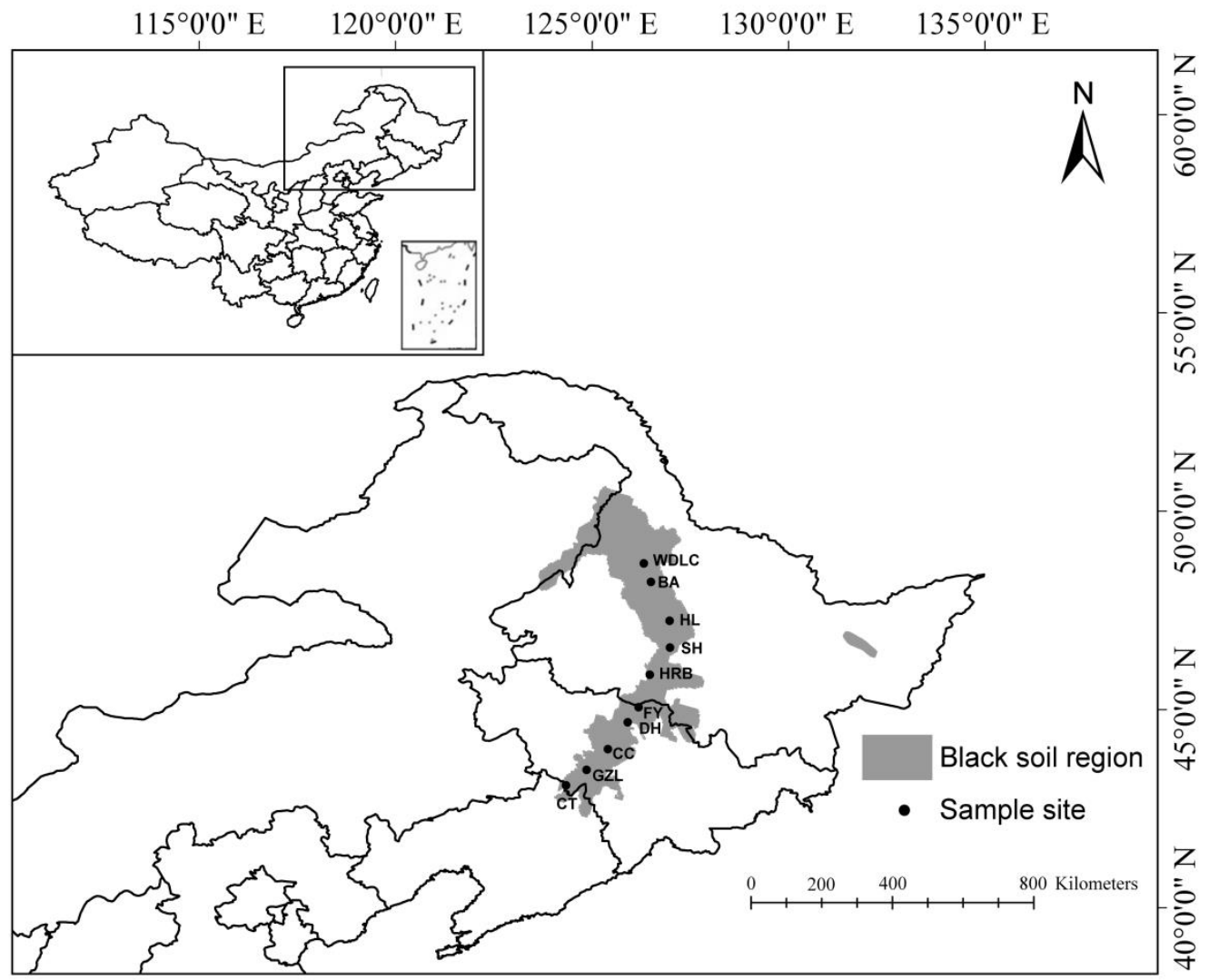

Figure 1. Ten soil sample locations in the black soil region of northeast China. The gray region indicates the representative black soil region of northeast China. The black circles represent the sampling sites: Wudalianchi (WDLC), Beian (BA), Hailun (HL), Suihua (SH), Harbin (HRB), Fuyu (FY), Dehui (DH), Changchun (CC), Gongzhuling (GZL), and Changtu (CT).

\subsection{Soil Property and Enzyme Activity Measurements}

Soil $\mathrm{pH}$ was measured in a 1:5 soil: water slurry using a calibrated $\mathrm{pH}$ meter (MettlerToledo FE 20, Greifensee, ZH, Switzerland). Soil organic carbon (SOC) content was measured by the external-heat potassium dichromate oxidation method [15]. Total nitrogen (TN) and total phosphorus (TP) contents were determined using a continuous flow analyzer (San ${ }^{++}$, Skalar, Breda, Holland).

Soil enzyme activities were quantified according to Guan [16]. Soil urease activity was determined using the phenol sodium hypochlorite colorimetry method, and soil invertase activity was determined using the 3,5-dinitrosalicylic alkaline colorimetry method.

\subsection{Glomalin-Related Soil Protein Measurements}

Glomalin-related soil protein (GRSP) was determined based on the method described in Wu et al. [17]. Briefly, $1 \mathrm{~g}$ soil was added to $8 \mathrm{~mL} 20 \mathrm{mM}$ sodium citrate solution (pH 7.0), autoclaved at $121^{\circ} \mathrm{C}$ for $30 \mathrm{~min}$, and centrifuged at $10,000 \times g$ for $3 \mathrm{~min}$. The supernatant was used to measure the easily extractable GRSP. The remaining precipitation was added to $8 \mathrm{~mL} 50 \mathrm{mM}$ sodium citrate solution ( $\mathrm{pH} \mathrm{8.0)}$, autoclaved at $121{ }^{\circ} \mathrm{C}$ for $60 \mathrm{~min}$, and centrifuged at $10,000 \times g$ for $3 \mathrm{~min}$. The supernatant was then used to measure the difficultly extractable GRSP. The supernatant was analyzed based on the Bradford assay [18]. In particular, $1 \mathrm{~mL}$ supernatant was extracted for each GRSP group and mixed with $5 \mathrm{~mL}$ Coomassie brilliant blue G-250 reagent while shaking. The absorbance was measured at $595 \mathrm{~nm}$ following $2 \mathrm{~min}$, and the corresponding protein content $\left(\mathrm{mg} \mathrm{g}^{-1}\right)$ was calculated according to the standard curve. Total GRSP was determined as the sum of the easily extractable GRSP and difficultly extractable GRSP. 


\subsection{DNA Extraction and MiSeq Sequencing}

DNA extraction and MiSeq sequencing were performed similarly to the previous research [14]. Soil sample DNA was extracted with $0.5 \mathrm{~g}$ soil using an E.Z.N.A Mag-Bind Soil DNA Kit (OMEGA, Irving, TX, USA) according to the manufacturer's instructions. The DNA extraction quality was determined by $0.8 \%$ agarose gel electrophoresis, and the DNA was quantified using an ultraviolet spectrophotometer (Nanodrop NC2000, Thermo Scientific, Waltham, MA, USA).

The ribosomal DNA was amplified via polymerase chain reaction (PCR). AMF-specific primer sets, namely AMV4.5NF (AAGCTCGTAGTTGAATTTCG) and AMDGR (CCCAACTATCCCTATTAATCAT) [19], were used in the PCR reaction. The reaction volume was $25 \mu \mathrm{L}$ containing $2 \mu \mathrm{L}$ of template DNA, $1 \mu \mathrm{L}$ forward primer $(10 \mu \mathrm{M}), 1 \mu \mathrm{L}$ reverse primer $(10 \mu \mathrm{M}), 2 \mu \mathrm{L}$ dNTPs $(2.5 \mathrm{mM}), 10 \mu \mathrm{L} 5 \times$ buffer, $0.25 \mu \mathrm{LQ} 5$ high-fidelity DNA polymerase (NEB, Ipswich, MA, USA), and $8.75 \mu \mathrm{L}$ of sterilized $\mathrm{ddH}_{2} \mathrm{O}$. The thermocycling conditions consisted of an initial denaturation at $98^{\circ} \mathrm{C}$ for $2 \mathrm{~min}$, followed by 25 cycles of $98^{\circ} \mathrm{C}$ for $15 \mathrm{~s}, 55^{\circ} \mathrm{C}$ for $30 \mathrm{~s}$, and $72{ }^{\circ} \mathrm{C}$ for $30 \mathrm{~s}$, and a final extension at $72{ }^{\circ} \mathrm{C}$ for $5 \mathrm{~min}$. PCR amplification products were detected via $2 \%$ agarose gel electrophoresis, and the obtained products were purified. According to the preliminary quantitative results of the electrophoresis, the PCR amplification products were used for fluorescence quantification using a Quant-iTPicoGreen dsDNA Assay Kit and a Microplate reader (FLx800, BioTek, Winooski, VT, USA). The sequencing library was then prepared using TruSeq Nano DNA LT Library Prep Kit (Illumina, San Diego, CA, USA). The PCR products were purified with AMPure XP Beads (Beckman, Atlanta, GE, USA). The purified DNA was sequenced on an Illumina MiSeq platform (Illumina, San Diego, CA, USA) with MiSeq Reagent Kit V3 (600 cycles, $2 \times 300$ bp paired-end) at Personal Biotechnology Co., Ltd. (Shanghai, China). The MiSeq sequence files were submitted to the NCBI Sequence Read Archive repository and are accessible via the BioProject PRJNA482549.

\subsection{Data Analysis}

Paired-end sequences (stored as FASTQ files) were screened using the sliding window approach, and poor-quality sequences (reads with length $<200 \mathrm{bp}$ and mean quality score $<20$ ) were removed. Quality filtering, chimera detection, and sequence detection and removal were performed using USEARCH v5.2.236 in QIIME v1.8.0 [20]. The obtained sequences were clustered into operational taxonomic units (OTUs) using an average neighbor algorithm with a cutoff of $97 \%$ similarity using UCLUST [21]. OTUs were assigned a taxonomic identity by BLAST search of the representative sequence on GenBank. Taxonomic assignments with a BLAST score $\geq 200$ were considered reliable, and OTUs not belonging to the Glomeromycota or with a BLAST score below 200 were discarded. The representative sequence of each OTU was searched against the MaarjAM database to confirm the identity or enhanced identification of the AMF OTUs [22]. OTUs with a relative abundance $<0.001 \%$ of the total reads of all samples were removed in order to improve the efficiency and accuracy of the data analysis. Because the sequencing depth varied across samples, the number of reads per sample were randomly re-sampled into an equal number to prevent bias. Rarefaction curves were employed to test whether the current sequencing depth was deep enough in reflecting the microbial diversity of the present community sample (Figure S1). The AMF taxonomic composition was classified using the OTUs and the Chao1 index was determined in order to evaluate AMF alpha diversity.

The Kruskal-Wallis test was used to evaluate differences in the soil properties, GRSP, OTU richness, and Chao1 index, and AMF taxon abundances using SPSS Statisticsv23 (SPSS Inc., Armonk, NY, USA). Pearson correlation was used to test the relationships between soil properties and the AMF alpha diversity or relative abundance of AMF taxa. A significance level of 0.05 was used for all tests performed.

AMF community composition analyses were based on relative abundance of OTUs per sample. Permutational multivariate analysis of variance (PERMANOVA, 999 permutations) was applied to test variations in AMF community compositions between land-use types 
via the adonis function of the 'vegan' package in R v3.4.1 (R Core Development team, 2017).Dissimilarities in AMF community composition were estimated using non-metric multidimensional scaling (NMDS) with Bray-Curtis distance via the 'vegan' package in R. Canonical correspondence analysis (CCA) was performed to explore the contributions of soil factors to AMF community composition using the 'vegan' package in $R$.

\section{Results}

\subsection{Overall Sequences Information}

Following the filtering of poor quality sequences and those with a length $<200 \mathrm{bp}$, a total of 1,896,837 and 2,145,244 sequences were determined for farmlands and woodlands, respectively. All sequences obtained were assigned to 5441 OTUs (97\% identity, belonging to 11 genera); 4298 and 4439 OTUs (belonging to 10 and 11 genera) were from the farmland and woodland, respectively.

\subsection{Edaphic Factors and GRSP}

Table 1 reported the mean values of different edaphic factors from each sample site. Mean SOC content varied approximately three-fold within the 10 sampling sites in farmland, and approximately two-fold within the 10 woodland sampling sites. Average contents of total $\mathrm{N}$ and total $p$ varied by approximately three-fold in both farmland and woodland sites. In terms of soil enzymes, average activities of urease varied two- and three-fold in farmland and woodland sites, respectively. In addition, average invertase activities varied 3.6 times in farmland and 2.9 times in woodland. Mean GRSP content exhibited similar variations in both farmland and woodland (approximately 1.5 times). Furthermore, Pearson's correlation analysis revealed a significant positive relationship between GRSP and SOC $(r=0.461, p=0.003$ and $r=0.764, p<0.001)$, TN $(r=0.350, p=0.029$ and $r=0.682, p<0.001)$ and TP $(r=0.506, p=0.001$ and $r=0.590, p<0.001)$ contents in farmland and woodland (Table S1).

\subsection{AMF Community Diversity}

The Chao1 index and OTU richness of all sample sites ranged within 344-1057 and 283-831, respectively (Figure 2). No significant differences were observed for the AMF diversity index $(p=0.664)$ and OTU richness $(p=0.712)$ between farmland and woodland. However, Pearson's correlation analysis demonstrated the significant correlation between the AMF diversity index and TP or SOC (Figure 3). Furthermore, a significant negative correlation was observed between the Chao1 index and TP $(r=-0.441, p=0.005)$ in farmland and SOC $(r=-0.380, p=0.019)$ in woodland. OTU richness was also significantly negatively correlated with TP $(r=-0.480, p=0.002)$ in farmland and SOC $(r=-0.330$, $p=0.04$ and $r=-0.345, p=0.034)$ in both farmland and woodland. 
Table 1. Sampling site location information and edaphic factors. The value of edaphic factors is mean \pm standard error.

\begin{tabular}{|c|c|c|c|c|c|c|c|c|c|c|c|c|c|c|c|c|c|}
\hline \multirow{2}{*}{ Sample } & \multirow{2}{*}{ Location } & \multirow{2}{*}{ Longitude } & \multirow{2}{*}{ Latitude } & \multicolumn{2}{|c|}{$\mathrm{pH}$} & \multicolumn{2}{|c|}{$\mathrm{TN}\left(\mathrm{mg} \mathrm{kg}^{-1}\right)$} & \multicolumn{2}{|c|}{ TP $\left(\mathrm{mg} \mathrm{kg}^{-1}\right)$} & \multicolumn{2}{|c|}{ SOC (\%) } & \multicolumn{2}{|c|}{ Urease $\left(\mathrm{mg} \mathrm{g}^{-1}\right)$} & \multicolumn{2}{|c|}{ Invertase $\left(\mathrm{mg} \mathrm{g}^{-1}\right)$} & \multicolumn{2}{|c|}{ GRSP $\left(\mathrm{mg} \mathrm{g}^{-1}\right)$} \\
\hline & & & & $F$ & W & F & W & F & $\mathrm{W}$ & $\mathbf{F}$ & $\mathrm{w}$ & $\mathrm{F}$ & W & $F$ & W & $F$ & W \\
\hline WDLC & Wudalianchi & $126.32^{\circ} \mathrm{E}$ & $48.68^{\circ} \mathrm{N}$ & $\begin{array}{c}7.02 \pm \\
0.04 \mathrm{abcA}\end{array}$ & $\begin{array}{c}6.80 \pm \\
0.06 \mathrm{abB}\end{array}$ & $\begin{array}{l}2330.55 \pm \\
147.15 \mathrm{aB}\end{array}$ & $\begin{array}{l}3212.93 \pm \\
156.06 \mathrm{aA}\end{array}$ & $\begin{array}{l}1154.14 \pm \\
122.92 \mathrm{aA}\end{array}$ & $\begin{array}{l}1235.52 \mathrm{I} \\
109.95 \mathrm{aA}\end{array}$ & $\begin{array}{c}3.15 \pm \\
0.10 \mathrm{abB}\end{array}$ & $\begin{array}{l}4.08 \pm \\
0.27 \mathrm{aA}\end{array}$ & $\begin{array}{l}19.90 \pm \\
4.28 \mathrm{abA}\end{array}$ & $\begin{array}{l}18.66 \pm \\
1.14 \mathrm{abA}\end{array}$ & $\begin{array}{c}0.66 \pm \\
0.02 \mathrm{abB}\end{array}$ & $\begin{array}{c}1.61 \pm \\
0.15 \mathrm{abA}\end{array}$ & $\begin{array}{c}0.97 \pm \\
0.17 \mathrm{aA}\end{array}$ & $\begin{array}{l}1.00 \pm \\
0.01 \mathrm{aA}\end{array}$ \\
\hline BA & Beian & $126.50^{\circ} \mathrm{E}$ & $48.21^{\circ} \mathrm{N}$ & $\begin{array}{c}6.63 \pm \\
0.07 \mathrm{abcB}\end{array}$ & $\begin{array}{l}7.98 \pm \\
0.22 \mathrm{aA}\end{array}$ & $\begin{array}{l}1997.70 \pm \\
226.42 \mathrm{aA}\end{array}$ & $\begin{array}{l}2369.54 \pm \\
90.59 \mathrm{abA}\end{array}$ & $\begin{array}{l}839.54 \pm \\
56.29 \mathrm{abA}\end{array}$ & $\begin{array}{l}990.23 \pm \\
35.58 \mathrm{aA}\end{array}$ & $\begin{array}{c}2.65 \pm \\
0.22 \mathrm{abA}\end{array}$ & $\begin{array}{l}3.05 \pm \\
0.18 \mathrm{aAA}\end{array}$ & $\begin{array}{l}14.88 \pm \\
1.85 \mathrm{abA}\end{array}$ & $\begin{array}{r}17.85 \pm \\
2.07 \mathrm{abA}\end{array}$ & $\begin{array}{c}0.74 \pm \\
0.11 \mathrm{abB}\end{array}$ & $\begin{array}{c}1.28 \pm \\
0.10 \mathrm{abA}\end{array}$ & $\begin{array}{c}0.64 \pm \\
0.04 \mathrm{abB}\end{array}$ & $\begin{array}{c}0.84 \pm \\
0.02 \mathrm{abA}\end{array}$ \\
\hline HL & Hailun & $126.97^{\circ} \mathrm{E}$ & $47.24^{\circ} \mathrm{N}$ & $\begin{array}{c}6.50 \pm \\
0.05 \mathrm{bcB}\end{array}$ & $\begin{array}{c}7.32 \pm \\
0.07 \mathrm{abA}\end{array}$ & $\begin{array}{c}2323.54 \pm \\
77.62 \mathrm{aA}\end{array}$ & $\begin{array}{c}2117.63 \pm \\
127.83 \mathrm{abcA}\end{array}$ & $\begin{array}{l}973.85 \pm \\
31.22 \mathrm{aA}\end{array}$ & $\begin{array}{l}655.56 \pm \\
30.76 \mathrm{abB}\end{array}$ & $\begin{array}{l}3.46 \pm \\
0.11 \mathrm{aA}\end{array}$ & $\begin{array}{l}3.15 \pm \\
0.04 \mathrm{aB}\end{array}$ & $\begin{array}{l}16.42 \pm \\
1.24 \mathrm{abA}\end{array}$ & $\begin{array}{l}11.24 \pm \\
0.73 \mathrm{abB}\end{array}$ & $\begin{array}{c}1.03 \pm \\
0.06 \mathrm{abB}\end{array}$ & $\begin{array}{c}1.47 \pm \\
0.14 \mathrm{abA}\end{array}$ & $\begin{array}{l}0.90 \pm \\
0.02 \mathrm{aA}\end{array}$ & $\begin{array}{c}0.97 \pm \\
0.04 \mathrm{aA}\end{array}$ \\
\hline $\mathrm{SH}$ & Suihua & $126.98^{\circ} \mathrm{E}$ & $46.56^{\circ} \mathrm{N}$ & $\begin{array}{l}5.92 \pm \\
0.02 \mathrm{cB}\end{array}$ & $\begin{array}{c}6.83 \pm \\
0.18 \mathrm{abA}\end{array}$ & $\begin{array}{l}1462.97 \pm \\
76.00 \mathrm{abA}\end{array}$ & $\begin{array}{c}1637.84 \pm \\
102.79 \text { abcA }\end{array}$ & $\begin{array}{l}862.11 \pm \\
83.80 \mathrm{abA}\end{array}$ & $\begin{array}{c}575.24 \pm \\
15.21 \mathrm{abA}\end{array}$ & $\begin{array}{c}2.13 \pm \\
0.04 \text { abcA }\end{array}$ & $\begin{array}{c}2.28 \pm \\
0.05 \mathrm{abA}\end{array}$ & $\begin{array}{l}16.31 \pm \\
0.76 \mathrm{abA}\end{array}$ & $\begin{array}{l}10.19 \pm \\
0.11 \mathrm{abB}\end{array}$ & $\begin{array}{l}0.47 \pm \\
0.03 \mathrm{bB}\end{array}$ & $\begin{array}{l}1.51 \pm \\
0.05 \mathrm{abA}\end{array}$ & $\begin{array}{l}0.92 \pm \\
0.09 \mathrm{aA}\end{array}$ & $\begin{array}{c}0.84 \pm \\
0.04 \mathrm{abA}\end{array}$ \\
\hline HRB & Harbin & $126.47^{\circ} \mathrm{E}$ & $45.88^{\circ} \mathrm{N}$ & $\begin{array}{c}7.16 \pm \\
0.08 \mathrm{abB}\end{array}$ & $\begin{array}{l}7.96 \pm \\
0.03 \mathrm{aA}\end{array}$ & $\begin{array}{r}1626.83 \pm \\
145.80 \mathrm{abA}\end{array}$ & $\begin{array}{c}1679.80 \pm \\
107.80 \text { abcA }\end{array}$ & $\begin{array}{l}558.03 \pm \\
18.40 \mathrm{abA}\end{array}$ & $\begin{array}{l}517.20 \pm \\
5.99 \mathrm{abB}\end{array}$ & $\begin{array}{c}2.20 \pm \\
0.02 \mathrm{abcB}\end{array}$ & $\begin{array}{c}2.43 \pm \\
0.07 \mathrm{abA}\end{array}$ & $\begin{array}{l}22.89 \pm \\
0.97 \mathrm{aA}\end{array}$ & $\begin{array}{l}14.64 \pm \\
1.22 \mathrm{abB}\end{array}$ & $\begin{array}{c}1.05 \pm \\
0.05 \mathrm{abB}\end{array}$ & $\begin{array}{l}2.00 \pm \\
0.27 \mathrm{aA}\end{array}$ & $\begin{array}{c}0.61 \pm \\
0.02 \mathrm{abA}\end{array}$ & $\begin{array}{c}0.66 \pm \\
0.03 \mathrm{bA}\end{array}$ \\
\hline FY & Fuyu & $126.18^{\circ} \mathrm{E}$ & $45.06^{\circ} \mathrm{N}$ & $\begin{array}{l}7.79 \pm \\
0.07 \mathrm{aA}\end{array}$ & $\begin{array}{l}7.82 \pm \\
0.15 \mathrm{aA}\end{array}$ & $\begin{array}{l}1220.32 \pm \\
156.30 \mathrm{abA}\end{array}$ & $\begin{array}{c}1666.38 \pm \\
190.15 \mathrm{abcA}\end{array}$ & $\begin{array}{l}658.30 \pm \\
19.14 \mathrm{abB}\end{array}$ & $\begin{array}{c}934.37 \pm \\
153.57 \mathrm{abA}\end{array}$ & $\begin{array}{c}2.01 \pm \\
0.03 \mathrm{abcB}\end{array}$ & $\begin{array}{c}2.44 \pm \\
0.19 \mathrm{abA}\end{array}$ & $\begin{array}{l}16.12 \pm \\
1.93 \mathrm{abA}\end{array}$ & $\begin{array}{l}24.73 \pm \\
1.72 \mathrm{aB}\end{array}$ & $\begin{array}{l}1.69 \pm \\
0.13 \mathrm{aA}\end{array}$ & $\begin{array}{l}2.05 \pm \\
0.18 \mathrm{aA}\end{array}$ & $\begin{array}{c}0.64 \pm \\
0.03 \mathrm{abA}\end{array}$ & $\begin{array}{c}0.76 \pm \\
0.06 \mathrm{abA}\end{array}$ \\
\hline $\mathrm{CC}$ & Changchun & $125.40^{\circ} \mathrm{E}$ & $44.00^{\circ} \mathrm{N}$ & $\begin{array}{c}6.95 \pm \\
0.07 \mathrm{abcB}\end{array}$ & $\begin{array}{c}7.11 \pm \\
0.02 \mathrm{abA}\end{array}$ & $\begin{array}{l}1596.88 \pm \\
117.69 \mathrm{abA}\end{array}$ & $\begin{array}{c}1245.72 \pm \\
160.00 \mathrm{bcA}\end{array}$ & $\begin{array}{l}637.42 \pm \\
67.27 \mathrm{abA}\end{array}$ & $\begin{array}{l}390.60 \pm \\
24.58 \mathrm{bA}\end{array}$ & $\begin{array}{c}1.87 \pm \\
0.02 \mathrm{abcA}\end{array}$ & $\begin{array}{l}1.82 \pm \\
0.08 \mathrm{bAA}\end{array}$ & $\begin{array}{l}15.24 \pm \\
1.15 \mathrm{abA}\end{array}$ & $\begin{array}{l}8.91 \pm \\
0.56 \mathrm{bB}\end{array}$ & $\begin{array}{l}1.51 \pm \\
0.06 \mathrm{aA}\end{array}$ & $\begin{array}{c}1.85 \pm \\
0.16 \mathrm{abA}\end{array}$ & $\begin{array}{l}0.56 \pm \\
0.03 \mathrm{bB}\end{array}$ & $\begin{array}{c}0.70 \pm \\
0.03 \mathrm{abA}\end{array}$ \\
\hline GZL & Gongzhuling & $124.86^{\circ} \mathrm{E}$ & $43.48^{\circ} \mathrm{N}$ & $\begin{array}{c}6.89 \pm \\
0.03 \mathrm{abcB}\end{array}$ & $\begin{array}{c}7.79 \pm \\
0.10 \mathrm{abA}\end{array}$ & $\begin{array}{l}1110.90 \pm \\
26.91 \mathrm{abB}\end{array}$ & $\begin{array}{l}1616.70 \pm \\
40.90 \mathrm{bcA}\end{array}$ & $\begin{array}{l}647.04 \pm \\
74.23 \mathrm{abA}\end{array}$ & $\begin{array}{l}430.95 \pm \\
47.93 \mathrm{abB}\end{array}$ & $\begin{array}{l}1.52 \pm \\
0.09 \mathrm{bcB}\end{array}$ & $\begin{array}{c}2.27 \pm \\
0.09 \mathrm{abA}\end{array}$ & $\begin{array}{l}11.81 \pm \\
1.62 \mathrm{bA}\end{array}$ & $\begin{array}{l}8.25 \pm \\
0.95 \mathrm{bA}\end{array}$ & $\begin{array}{c}0.92 \pm \\
0.18 \mathrm{abA}\end{array}$ & $\begin{array}{l}1.42 \pm \\
0.14 \mathrm{abA}\end{array}$ & $\begin{array}{c}0.70 \pm \\
0.04 \mathrm{abA}\end{array}$ & $\begin{array}{c}0.68 \pm \\
0.01 \mathrm{abA}\end{array}$ \\
\hline CT & Changtu & $124.33^{\circ} \mathrm{E}$ & $43.08^{\circ} \mathrm{N}$ & $\begin{array}{l}6.51 \pm \\
0.15 \mathrm{abcB}\end{array}$ & $\begin{array}{c}7.35 \pm \\
0.12 \mathrm{abA}\end{array}$ & $\begin{array}{l}775.17 \pm \\
37.28 \mathrm{bB}\end{array}$ & $\begin{array}{l}1121.36 \pm \\
47.99 \mathrm{cdA}\end{array}$ & $\begin{array}{l}373.51 \pm \\
47.66 \mathrm{bcB}\end{array}$ & $\begin{array}{l}424.04 \pm \\
47.01 \mathrm{abA}\end{array}$ & $\begin{array}{l}1.10 \pm \\
0.09 \mathrm{cB}\end{array}$ & $\begin{array}{c}2.08 \pm \\
0.10 \mathrm{abA}\end{array}$ & $\begin{array}{l}12.20 \pm \\
1.33 \mathrm{bA}\end{array}$ & $\begin{array}{l}8.80 \pm \\
0.87 \mathrm{bA}\end{array}$ & $\begin{array}{l}0.57 \pm \\
0.10 \mathrm{bA}\end{array}$ & $\begin{array}{c}0.71 \pm \\
0.11 \mathrm{bA}\end{array}$ & $\begin{array}{c}0.62 \pm \\
0.03 \mathrm{abA}\end{array}$ & $\begin{array}{c}0.69 \pm \\
0.03 \mathrm{abA}\end{array}$ \\
\hline
\end{tabular}

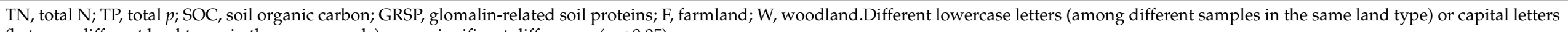
(between different land types in the same sample) mean significant differences $(p<0.05)$. 


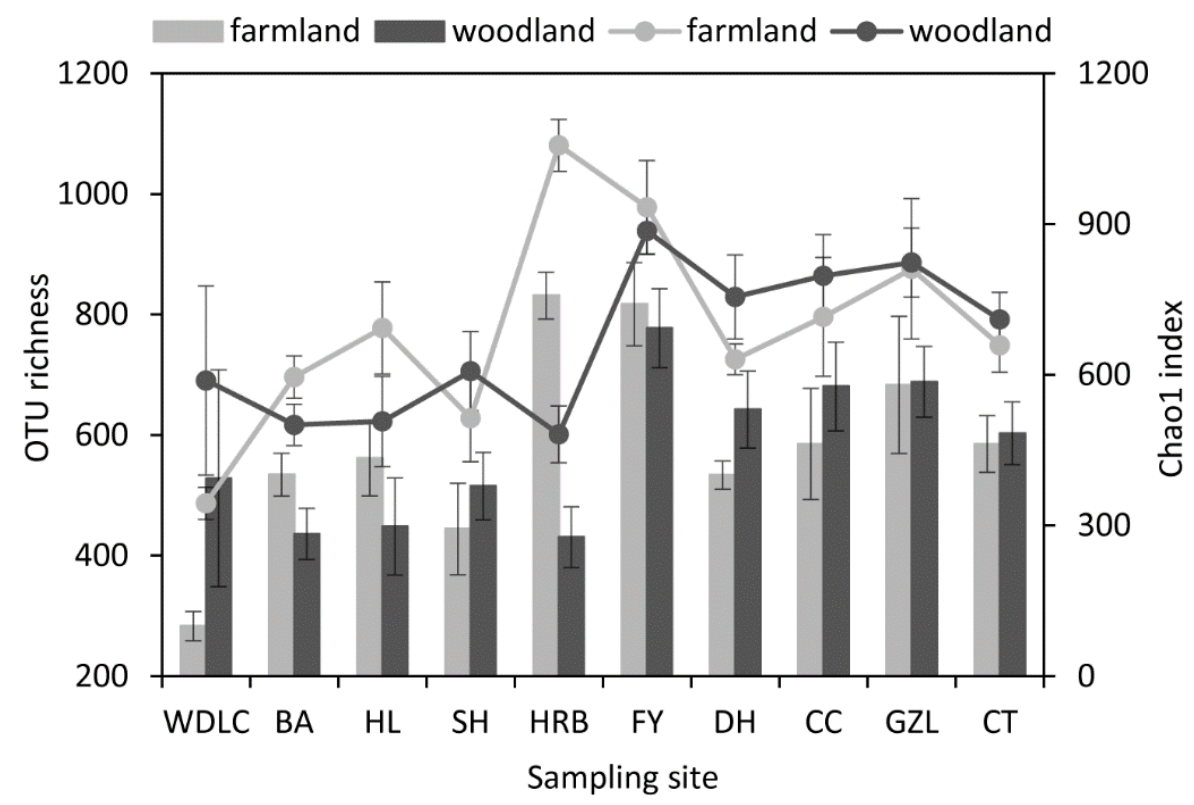

Figure 2. OTU richness (represented by bar graph) and Chao1 index (represented by line chart) of the arbuscular mycorrhizal fungal community at 20 farmland and woodland sampling sites (WDLC, Wudalianchi; BA, Beian; HL, Hailun; SH, Suihua; HRB, Harbin; FY, Fuyu; DH, Dehui; CC, Changchun; GZL, Gongzhuling; and CT, Changtu). Values are mean \pm standard error.

(a)

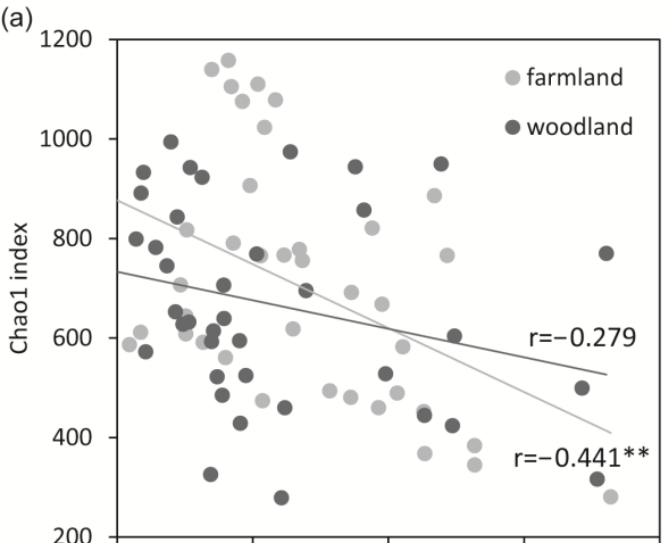

(b)

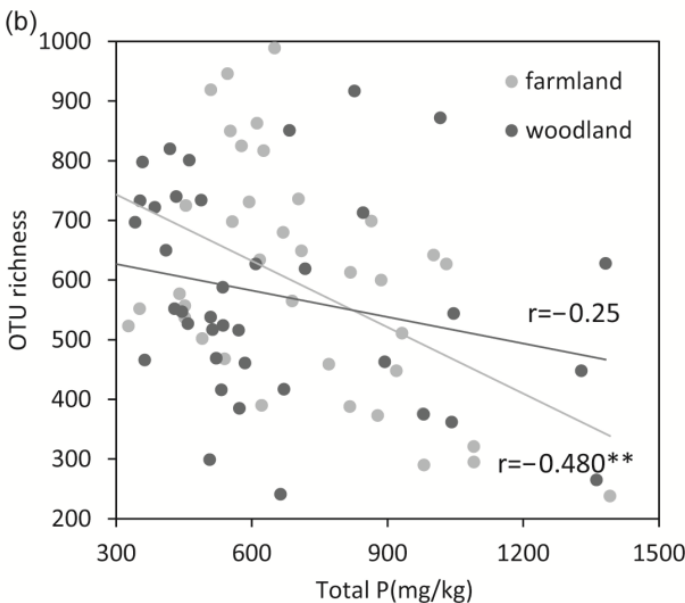

(c)

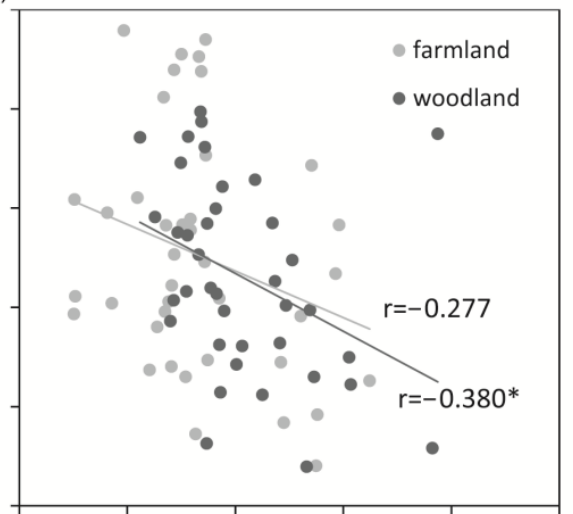

(d)

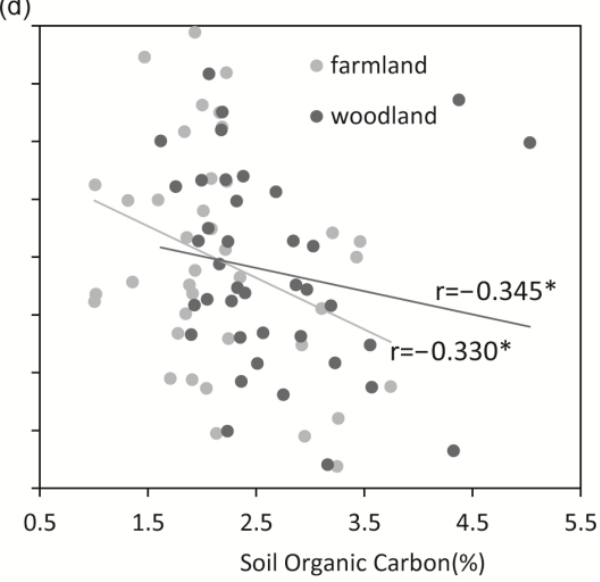

Figure 3. Relationship between arbuscular mycorrhizal fungal Chao1 index and total $p$ or SOC $(\mathbf{a}, \mathbf{c})$ and OTU richness and total $p$ or SOC $(\mathbf{b}, \mathbf{d})$ of the farmland and woodland sampling sites. ${ }^{*} p<0.05$ and ${ }^{* *} p<0.01$ by Turkey's test. 


\subsection{Relative Abundance of AMF Taxa}

Taxonomical classification identified 4 orders (Paraglomerales, Glomerales, Archaeosporales, and Diversisporales), 8 families (Paraglomeraceae, Claroideoglomeraceae, Glomeraceae, Archaeosporaceae, Ambisporaceae, Gigasporaceae, Acaulosporaceae. and Diversisporaceae), and 11 genera (Paraglomus, Claroideoglomus, Glomus, Archaeospora, Ambispora, Gigaspora, Scutellospora, Acaulospora, Septoglomus, Diversispora, and Redeckera) belonging to phylum Glomeromycota in all sampling sites. The species name and classification system of AMF taxonomy referred to Redecker et al. [23].The relative abundances of AMF taxa were shown in Table S2 and Figure 4. At the order taxon, Paraglomerales and Glomerales made up more than $90 \%$ of the total. Paraglomerales dominated in woodland and Glomerales in farmland. The mean relative abundance of Paraglomerales was higher in woodland compared to farmland, while the opposite was true for Glomerales and Diversisporales. At the family level, Paraglomeraceae, Claroideoglomeraceae, and Glomeraceae were identified as the most abundant (more than $90 \%$ ), with average relative abundances of $41.70 \%, 30.10 \%$, and $20.80 \%$ in farmland and $64.88 \%, 20.13 \%$, and $10.05 \%$ in woodland, respectively. At the genus level, Paraglomus, Claroideoglomus, and Glomus were observed to make up more than $90 \%$ of the total, with average relative abundances of $41.70 \%, 30.10 \%$, and $20.70 \%$ in farmland and $64.88 \%, 20.13 \%$, and $10.03 \%$ in woodland, respectively. Furthermore, 11 and 10 genera were identified in woodland and farmland, respectively.

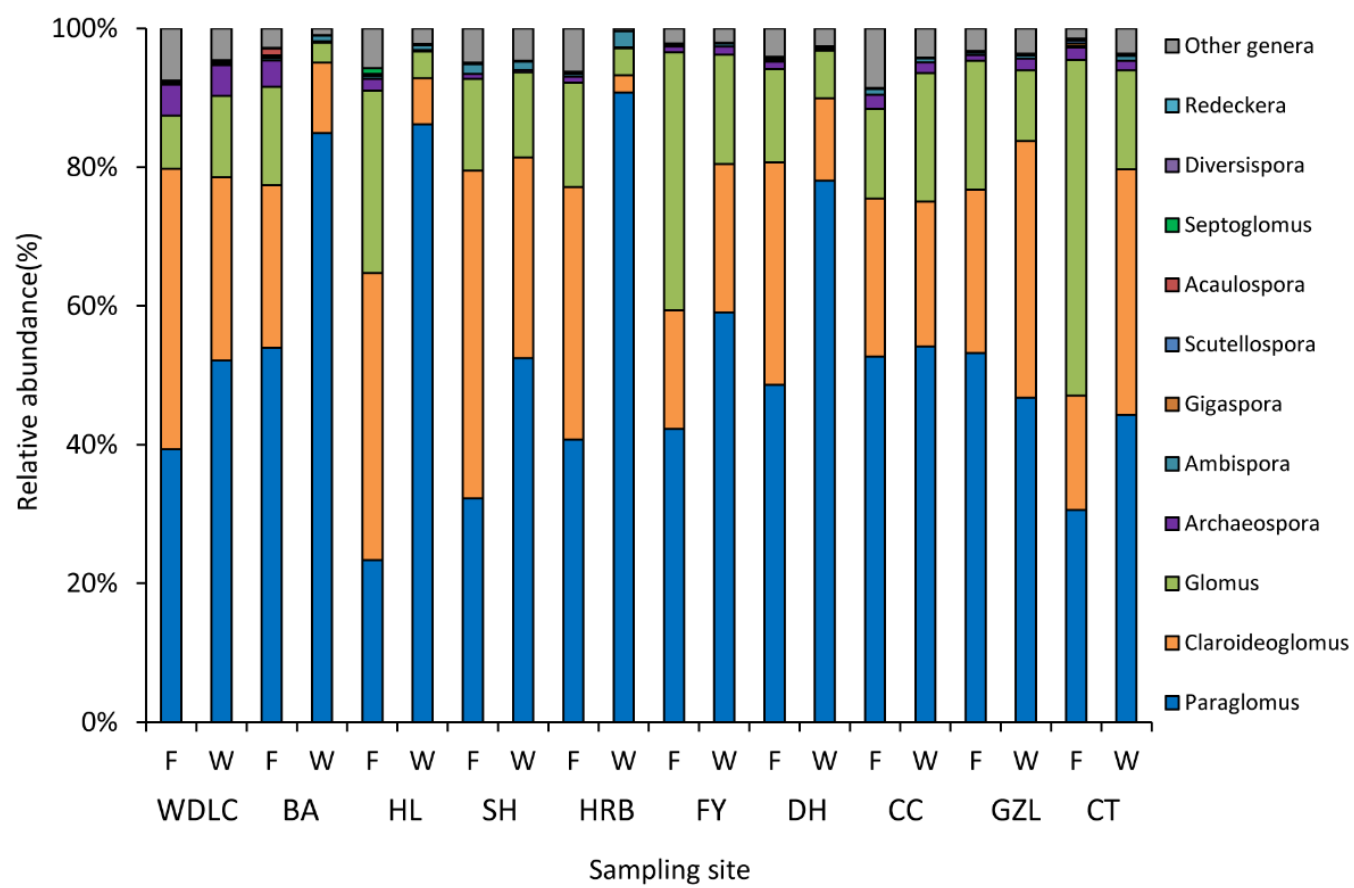

Figure 4. Relative abundance of the arbuscular mycorrhizal fungi genera at the 20 farmland or woodland sampling sites (WDLC, Wudalianchi; BA, Beian; HL, Hailun; SH, Suihua; HRB, Harbin; FY, Fuyu; DH, Dehui; CC, Changchun; GZL, Gongzhuling; and CT, Changtu). F and W represent farmland and woodland respectively.

The soil properties were observed to have an impact on the relative abundance of several AMF taxa (Table S3). At the genus level, the relative abundance of Paraglomus was significantly positive associated with $\mathrm{pH}(r=0.357, p=0.001)$, TN $(r=0.238, p=0.036)$ and invertase activity $(r=0.431, p<0.001)$, while Claroideoglomus was negative associated with $\mathrm{pH}(r=-0.306, p=0.006)$, and invertase activity $(r=-0.369, p=0.001)$. Glomus was negative associated with TN $(r=-0.384, p=0.001)$, SOC $(r=-0.385, p=0.001)$, and invertase activity $(r=-0.225, p=0.047)$. Archaeospora was positively correlated with TP $(r=0.304, p=0.007)$. Gigaspora was negatively correlated with $\mathrm{pH}(r=-0.366, p=0.001)$ and invertase activity $(r=-0.376, p=0.001)$. Scutellospora, Acaulospora, and Diversispora 
was negative associated with invertase activity $(r=-0.261, p=0.021 ; r=-0.238, p=0.036$; and $r=-0.239, p=0.035$, respectively). Redeckera was significantly positive associated with $\mathrm{TN}(r=0.391, p<0.001), \mathrm{TP}(r=0.332, p=0.003)$, and SOC $(r=0.379, p=0.001)$.

\subsection{AMF Community Compositions}

The NMDS analysis was performed to identify the differences in the AMF community composition between farmland and woodland (Figure 5). The stress value of 0.156 gave a good representation of the dissimilarity in AMF communities in farmland and woodland. PERMANOVA based on Bray-Curtis distance indicated that AMF community composition differed between farmland and woodland $(\mathrm{F}=5.758, p<0.001$; Table 2$)$.

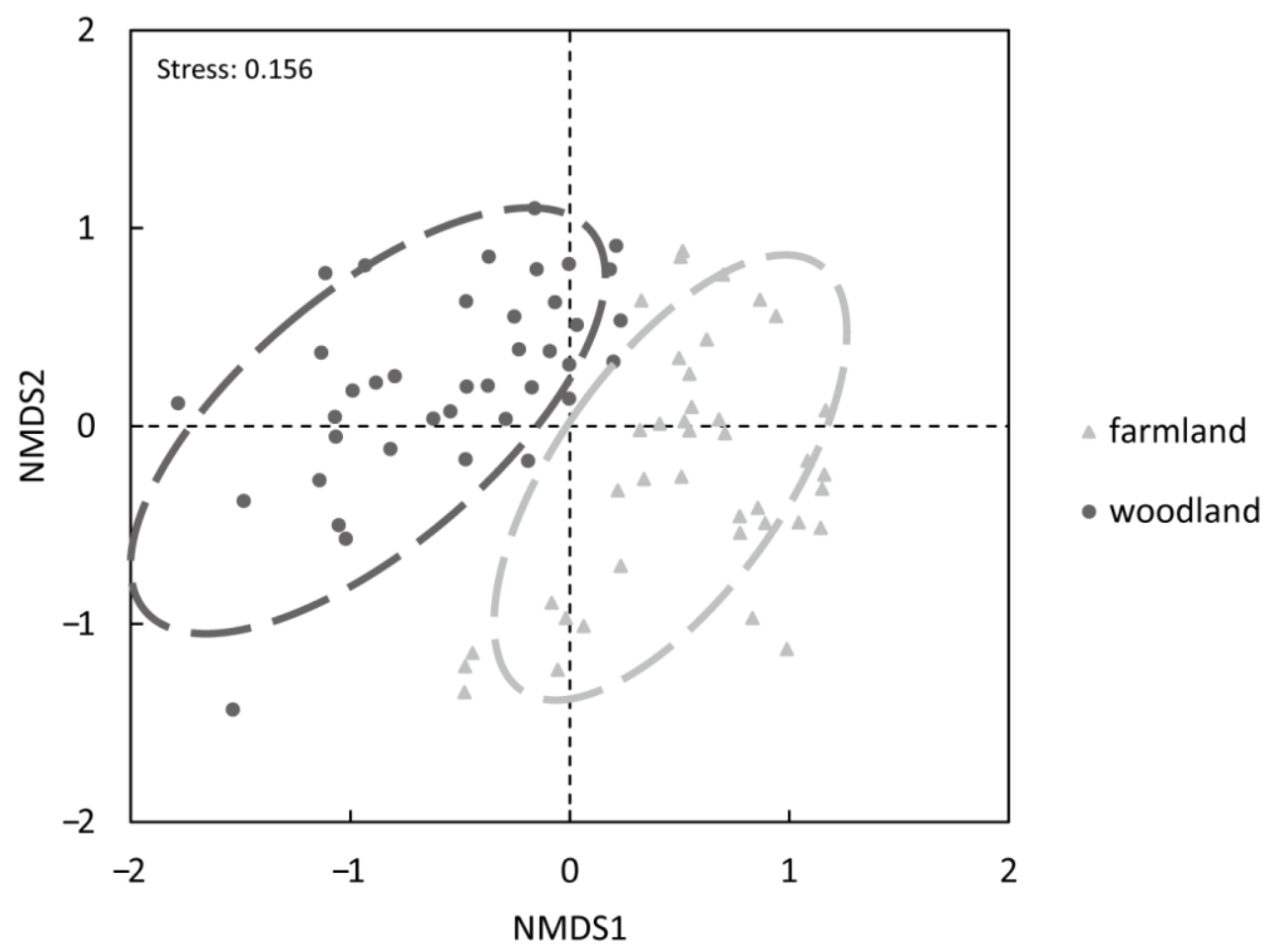

Figure 5. Non-metric multidimensional scaling (NMDS) ordination of arbuscular mycorrhizal fungal community composition in farmland and woodland.

Table 2. PERMANOVA (permutational multivariate analysis of variance) based on Bray-Curtis distance showing the dissimilarity of AMF communities between farmland and woodland.

\begin{tabular}{ccccccc}
\hline & df & Sums of Squares & Mean Squares & F Model & $\mathbf{R}^{\mathbf{2}}$ & $p$ \\
\hline Types & 1 & 2.225 & 2.225 & 5.758 & 0.070 & $<0.001$ \\
Residuals & 76 & 29.372 & 0.386 & & 0.930 & \\
Total & 77 & 31.597 & & & 1 & \\
\hline
\end{tabular}

CCA analysis was performed to further determine the significant edaphic factors shaping the AMF community composition. The results showed that the AMF community were significantly influenced by SOC $\left(R^{2}=0.807, p<0.001\right)$, TN $\left(R^{2}=0.733, p<0.001\right)$, $\mathrm{TP}\left(R^{2}=0.525, p<0.001\right), \mathrm{pH}\left(R^{2}=0.540, p<0.001\right)$, and invertase activity $\left(R^{2}=0.642\right.$, $p<0.001)$. However, urease activity $\left(R^{2}=0.031, p=0.318\right)$ did not show the influence to AMF community (Figure 6). 


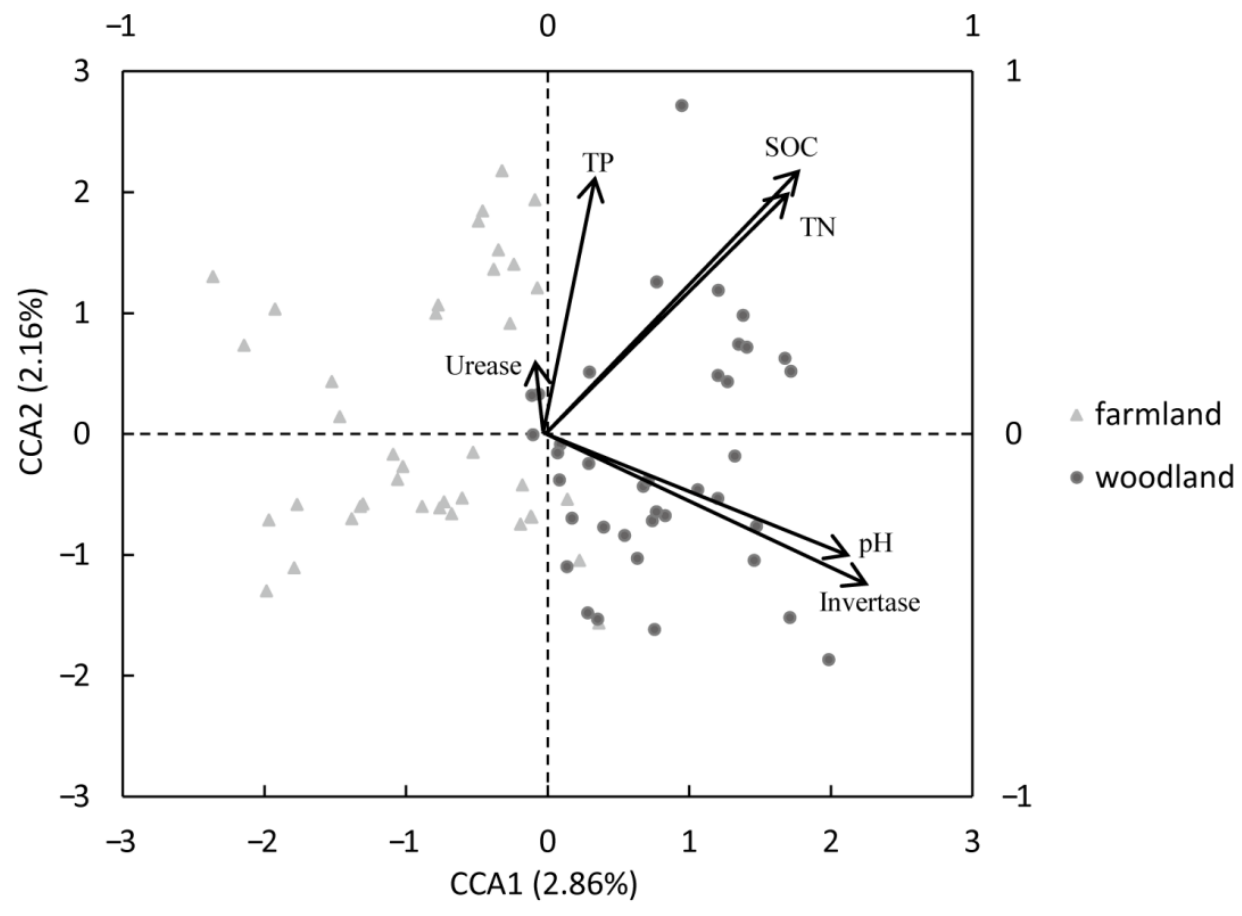

Figure 6. Canonical correspondence analysis (CCA) of the arbuscular mycorrhizal fungal community composition and edaphic factors of farmland and woodland. Edaphic factors include $\mathrm{pH}$, soil organic carbon (SOC), total $\mathrm{N}(\mathrm{TN})$, total $p(\mathrm{TP})$, urease activity and invertase activity.

\section{Discussion}

Our results demonstrated the variations in AMF community compositions between farmland and woodland in the black soil region of northeast China. A total of 4 orders, 8 families, and 11 genera were identified, belonging to phylum Glomeromycota. Glomerales and Paraglomerales were determined as the dominant order in farmland and woodland, respectively (Table S2; Figure 4). In the current study, the relative abundance of Glomeraceae was higher in farmland than woodland. This is attributed to their ability to produce large numbers of spores and hypha, as well as their greater adaptability to variable and disturbed environments [24,25]. This is in agreement with Marinho et al. [13], whereby dominant taxa were associated with a strong ability to adapt to new and variable environments. It is unanimously agreed upon that the dominant taxa vary with land-use types, despite uncertainty associate with the exact identification of dominant taxa. Such inconsistencies, which may be attributed to differences in habitats, sites, and the degree of anthropogenic disturbances, require further study.

No significant differences were observed between land-use types on the AMF alpha diversity (Chao 1 index) in this study (Figure 2). However, related researches had identified lower AMF diversity in farmland compared to woodland [9,10], due to the reduction in AMF diversity for high disturbance and land-use intensity in ecosystems. Anthropogenic environments or disturbed land may lead to a reduction and even the loss of AMF species, as some species are less adaptable to variable environments compared to others. We found no discrepancies between farmland and woodland on the $\alpha$-diversity index of AMF, which may be due to the fact that black soils are fertile and disturbances may not seriously reduce soil nutrients.

AMF community composition is a function of both biological and non-biological factors. Řezáčová et al. [26] identified factors responsible for shifts in soil AMF communities among a complete set of environmental and spatial descriptors, combining soil, vegetation, climatic, and geographical characteristics. Edaphic factors have an impact on AMF due to their direct contact with the soil environment. Numerous studies had focused on the impact of soil factors on AMF community, including soil $\mathrm{pH}$ [27] and organic carbon [28], and 
phosphorus [29] contents. Soil $\mathrm{pH}$, a key soil property, had been proven as critical for the AMF community composition across different land-use types [11,30]. Our results indicated that the relative abundance of several AMF genera, including Paraglomus, Claroideoglomus, and Gigaspora, was significantly affected by $\mathrm{pH}$ (Table S3). Different AMF taxa had different soil $\mathrm{pH}$ preferences, for example, acidic soils (e.g., Gigaspora, Entrophospora, Sclerocystis) or higher $\mathrm{pH}$ value (e.g., Glomus) [31]. Liming had been reported to regulate the number of spores and root colonization of $\mathrm{AMF}$, indicating that $\mathrm{pH}$ had a direct effect on the growth of AMF, impacting the germination of spores, the growth of hyphae, root colonization, and ultimately, AMF colonization, altering the community composition [32,33]. In addition, acid soil could also inhibit the normal growth and development of aboveground plants, indirectly affecting the AMF colonization and community composition [34].

The negative effect of high $\mathrm{P}$ on AMF diversity and community composition has been widely recognized $[2,35,36]$. In particular, high $P$ content in soil nutrients inhibit the growth, reproduction, development, functional expression, sporulation rate, mycelia growth, and community diversity of AMF. Our study revealed a significant negative correlation between the Chao1 index and OTU richness of the AMF community with total $p$ in farmland (Figure 3). Xiang et al. [9] determined that AMF diversity may not be directly affected by land-use type, highlighting the possible indirect impact of soil available phosphorus. This is attributed to the reduction in the AMF carbohydrates supply from plants via high $p$ concentrations in the soil, consequently resulting in the selection of specific AMF groups or group losses due to a general decline in community size.

SOC was considered to affect the AMF community composition [37,38]. High SOC content can provide more carbohydrates, which can promote the spore germination and hyphae growth of AMF, affecting their community composition $[39,40]$. Our results demonstrated that AMF $\alpha$-diversity index and community composition were significantly affected by SOC contents in both land-use types (Figure 3; Table S3). The effect of SOC content on AMF communities may be a result of the direct effect of land management on soil properties [9]. Moreover, our study revealed the correlation between TN and AMF community composition. The accumulation of SOC in the presence of sufficient $\mathrm{N}$ had been demonstrated in the literature, improving the relative richness of the fungal community [41]. Therefore, the effect of $\mathrm{N}$ on the AMF community may be regulated by SOC. In addition, the role of SOC in regulating the AMF community is still unknown, with further research required to clarify this. It is commonly agreed upon that soil enzyme activity is closely relevant to soil fertility. Urease can regulate the conversion of soil nitrogen, and invertase plays an important role in the cycle of SOC [42]. The increase in soil enzyme activity has been associated with the increase in organic matter input and the fixation of $\mathrm{C}$ and $\mathrm{N}$ during soil organic matter decomposition [43]. Therefore, the effect of enzyme activity on the AMF community may be an indirect effect through SOC.

GRSP is a glycoprotein containing metal ion secreted by the AMF hyphae and is difficult to decompose [44]. Singh et al. [45] found that GRSP content was positively correlated with SOC content in different land-use systems, including forest, fallow, and agriculture. The carbon concentration in GRSP accounts for approximately $25 \%$ of the soil carbon pool [46]. In the current study, GRSP content exhibited a significant positive correlation with some soil properties (e.g., SOC, TN, and TP contents; Table S1), which suggested the close relationship between AMF community and soil fertility, eventually to be used monitoring the soil quality.

Our results indicated soil $\mathrm{pH}, \mathrm{SOC}, \mathrm{TN}, \mathrm{TP}$, and invertase as the major impacting factor on AMF community composition across land-use types in the black soil zone of northeast China. This was consistent with previous studies [37,47]. However, only considering the edaphic factors may not accurately reflect the actual distribution of AMF community in the different land types. Different land-use types differ in many ways, including aboveground vegetation communities, underground biological communities, soil properties, and anthropogenic factors, which should be considered. This was highlighted in Lu et al. [48] and Luo et al. [38]. Actually, historical factors are also important for AMF community 
composition. AMF community can be recorded in a certain place since AMF species were able to stably establish their functions in that place. Further study is required to consider historical factors and reveal how the edaphic factors regulate the AMF community, as separating the effects of edaphic factors and land use types proves to be a difficult task [38]

\section{Conclusions}

The current study demonstrates the differences in AMF community compositions between farmland and wood land located within the black soil region of northeast China. The classification results obtained through the sequences indicated the region is rich in AMF communities. All four orders of Glomeromycota were detected in both farmland and woodland, yet the two land-use types exhibited distinct dominant orders (Paraglomerales in woodland but Glomerales in farmland). The edaphic factors, including soil $\mathrm{pH}, \mathrm{SOC}, \mathrm{TN}$, $\mathrm{TP}$, and invertase, were essential influencing factors for the AMF community composition of the two land-use types. In future agricultural production, attention should be paid to monitoring and regulating the reasonable increase or decrease of different soil properties in order to protect and take full advantage of AMF resources. Moreover, we identified the close relationship between several edaphic factors and SOC content. Therefore, future research should focus on the connection between SOC content and the AMF community, with the aim of improving AMF diversity and soil fertility due to their ability to promote each other and their positive role in the ecological environment.

Supplementary Materials: The following are available online at https: / /www.mdpi.com/article/ 10.3390/agriculture11090866/s1, Figure S1: Rarefaction curves showing the Chao1 index of different samples. Table S1: Pearson's correlation coefficients between soil properties and glomalin-related soil protein (GRSP). Table S2: Relative abundance of arbuscular mycorrhizal fungal classes, orders, families at 20 sampling sites. Table S3: Pearson's correlation coefficients between relative abundance of arbuscular mycorrhizal fungal orders, families, genera and edaphic factors.

Author Contributions: Conceptualization, X.Z.; Data Curation, W.Y.; Formal Analysis, W.Y. and M.Z.; Funding Acquisition, X.Z.; Investigation, W.Y. and M.Z.; Methodology, X.Z.; Project Administration, F.S. and X.Z.; Resources, F.S., S.L. and X.L.; Supervision, F.S. and X.Z.; Writing-Original Draft Preparation, W.Y.; Writing-Review \& Editing, X.Z. All authors have read and agreed to the published version of the manuscript.

Funding: This work was supported by the Science \& Technology Development Program of Jilin Province (20190201122JC).

Institutional Review Board Statement: Not applicable.

Informed Consent Statement: Not applicable.

Data Availability Statement: The data are available on request to the authors.

Conflicts of Interest: The authors declare no conflict of interest.

\section{References}

1. Smith, S.; Read, D. Mycorrhizal Symbiosis, 3rd ed.; Academic Press: London, UK, 2008; ISBN 9780123705266.

2. Smith, S.E.; Smith, F.A. Roles of Arbuscular Mycorrhizas in Plant Nutrition and Growth: New Paradigms from Cellular to Ecosystem Scales. Annu. Rev. Plant Biol. 2011, 62, 227-250. [CrossRef]

3. Mathur, S.; Jajoo, A. Arbuscular mycorrhizal fungi protects maize plants from high temperature stress by regulating photosystem II heterogeneity. Ind. Crop. Prod. 2020, 143, 111934. [CrossRef]

4. Zhang, X.; Zhang, H.; Zhang, Y.; Liu, Y.; Zhang, H.; Tang, M. Arbuscular mycorrhizal fungi alter carbohydrate distribution and amino acid accumulation in Medicago truncatula under lead stress. Environ. Exp. Bot. 2020, 171, 103950. [CrossRef]

5. Zhu, X.; Yang, W.; Song, F.; Li, X. Diversity and composition of arbuscular mycorrhizal fungal communities in the cropland black soils of China. Glob. Ecol. Conserv. 2020, 22, e00964. [CrossRef]

6. Liu, X.; Lee Burras, C.; Kravchenko, Y.S.; Duran, A.; Huffman, T.; Morras, H.; Studdert, G.; Zhang, X.; Cruse, R.M.; Yuan, X. Overview of Mollisols in the world: Distribution, land use and management. Can. J. Soil Sci. 2012, 92, 383-402. [CrossRef]

7. Xu, X.Z.; Xu, Y.; Chen, S.C.; Xu, S.G.; Zhang, H.W. Soil loss and conservation in the black soil region of Northeast China: A retrospective study. Environ. Sci. Policy 2010, 13, 793-800. [CrossRef] 
8. Liu, X.B.; Zhang, X.Y.; Wang, Y.X.; Sui, Y.Y.; Zhang, S.L.; Herbert, S.J.; Ding, G. Soil degradation: A problem threatening the sustainable development of agriculture in Northeast China. Plant Soil Environ. 2010, 56, 87-97. [CrossRef]

9. Xiang, D.; Verbruggen, E.; Hu, Y.; Veresoglou, S.D.; Rillig, M.C.; Zhou, W.; Xu, T.; Li, H.; Hao, Z.; Chen, Y.; et al. Land use influences arbuscular mycorrhizal fungal communities in the farming-pastoral ecotone of northern China. New Phytol. 2014, 204, 968-978. [CrossRef] [PubMed]

10. Xu, M.; Li, X.; Cai, X.; Li, X.; Christie, P.; Zhang, J. Land use alters arbuscular mycorrhizal fungal communities and their potential role in carbon sequestration on the Tibetan Plateau. Sci. Rep. 2017, 7, 3067. [CrossRef]

11. Bainard, L.D.; Chagnon, P.L.; Cade-Menun, B.J.; Lamb, E.G.; LaForge, K.; Schellenberg, M.; Hamel, C. Plant communities and soil properties mediate agricultural land use impacts on arbuscular mycorrhizal fungi in the Mixed Prairie ecoregion of the North American Great Plains. Agric. Ecosyst. Environ. 2017, 249, 187-195. [CrossRef]

12. Vályi, K.; Rillig, M.C.; Hempel, S. Land-use intensity and host plant identity interactively shape communities of arbuscular mycorrhizal fungi in roots of grassland plants. New Phytol. 2015, 205, 1577-1586. [CrossRef] [PubMed]

13. Marinho, F.; Oehl, F.; da Silva, I.R.; Coyne, D.; da Nobrega Veras, J.S.; Maia, L.C. High diversity of arbuscular mycorrhizal fungi in natural and anthropized sites of a Brazilian tropical dry forest (Caatinga). Fungal Ecol. 2019, 40, 82-91. [CrossRef]

14. Zhu, X.; Yang, W.; Sun, L.; Song, F.; Li, X. Anthropogenic land use changes diversity and structure of arbuscular mycorrhizal fungal communities at 100-m scale in northeast China. Arch. Agron. Soil Sci. 2020, 67, 778-792. [CrossRef]

15. Bao, S.D. Soil Agro-Chemistry Analyses; Chinese Agriculture Press: Beijing, China, 2005. (In Chinese)

16. Guan, S.Y. Soil Enzymes and Research Methods; Chinese Agriculture Press: Beijing, China, 1996. (In Chinese)

17. Wu, Q.S.; Cao, M.Q.; Zou, Y.N.; He, X.H. Direct and indirect effects of glomalin, mycorrhizal hyphae, and roots on aggregate stability in rhizosphere of trifoliate orange. Sci. Rep. 2014, 4, 5823. [CrossRef]

18. Bradford, M.M. A rapid and sensitive method for the quantitation of microgram quantities of protein utilizing the principle of protein-dye binding. Anal. Biochem. 1976, 72, 248-252. [CrossRef]

19. Van Geel, M.; Busschaert, P.; Honnay, O.; Lievens, B. Evaluation of six primer pairs targeting the nuclear rRNA operon for characterization of arbuscular mycorrhizal fungal (AMF) communities using 454 pyrosequencing. J. Microbiol. Methods 2014, 106, 93-100. [CrossRef] [PubMed]

20. Caporaso, J.G.; Kuczynski, J.; Stombaugh, J.; Bittinger, K.; Bushman, F.D.; Costello, E.K.; Fierer, N.; Pẽa, A.G.; Goodrich, J.K.; Gordon, J.I.; et al. QIIME allows analysis of high-throughput community sequencing data. Nat. Methods 2010, 7, 335-336. [CrossRef] [PubMed]

21. Edgar, R.C. Search and clustering orders of magnitude faster than BLAST. Bioinformatics 2010, 26, 2460-2461. [CrossRef] [PubMed]

22. Parvin, S.; Van Geel, M.; Yeasmin, T.; Lievens, B.; Honnay, O. Variation in arbuscular mycorrhizal fungal communities associated with lowland rice (Oryza sativa) along a gradient of soil salinity and arsenic contamination in Bangladesh. Sci. Total Environ. 2019, 686, 546-554. [CrossRef] [PubMed]

23. Redecker, D.; Schüßler, A.; Stockinger, H.; Stürmer, S.L.; Morton, J.B.; Walker, C. An evidence-based consensus for the classification of arbuscular mycorrhizal fungi (Glomeromycota). Mycorrhiza 2013, 23, 515-531. [CrossRef]

24. Öpik, M.; Moora, M.; Liira, J.; Zobel, M. Composition of root-colonizing arbuscular mycorrhizal fungal communities in different ecosystems around the globe. J. Ecol. 2006, 94, 778-790. [CrossRef]

25. Higo, M.; Tatewaki, Y.; Gunji, K.; Kaseda, A.; Isobe, K. Cover cropping can be a stronger determinant than host crop identity for arbuscular mycorrhizal fungal communities colonizing maize and soybean. Peer] 2019, 7, e6403. [CrossRef] [PubMed]

26. Řezáčová, V.; Slavíková, R.; Konvalinková, T.; Zemková, L.; Řezáč, M.; Gryndler, M.; Šmilauer, P.; Gryndlerová, H.; Hršelová, H.; Bukovská, P.; et al. Geography and habitat predominate over climate influences on arbuscular mycorrhizal fungal communities of mid-European meadows. Mycorrhiza 2019, 29, 567-579. [CrossRef] [PubMed]

27. Huang, Z.; Zhao, F.; Wang, M.; Qi, K.; Wu, J.; Zhang, S. Soil chemical properties and geographical distance exerted effects on arbuscular mycorrhizal fungal community composition in pear orchards in Jiangsu Province, China. Appl. Soil Ecol. 2019, 142, 18-24. [CrossRef]

28. Hu, Y.; Rillig, M.C.; Xiang, D.; Hao, Z.; Chen, B. Changes of AM Fungal Abundance along Environmental Gradients in the Arid and Semi-Arid Grasslands of Northern China. PLoS ONE 2013, 8, e57593. [CrossRef] [PubMed]

29. Xu, J.; Liu, S.; Song, S.; Guo, H.; Tang, J.; Yong, J.W.H.; Ma, Y.; Chen, X. Arbuscular mycorrhizal fungi influence decomposition and the associated soil microbial community under different soil phosphorus availability. Soil Biol. Biochem. 2018, 120, 181-190. [CrossRef]

30. Boeraeve, M.; Honnay, O.; Jacquemyn, H. Local abiotic conditions are more important than landscape context for structuring arbuscular mycorrhizal fungal communities in the roots of a forest herb. Oecologia 2019, 190, 149-157. [CrossRef] [PubMed]

31. Da Silva, G.A.; Trufem, S.F.B.; Saggin, O.J.; Maia, L.C. Arbuscular mycorrhizal fungi in a semiarid copper mining area in Brazil. Mycorrhiza 2005, 15, 47-53. [CrossRef] [PubMed]

32. Coughlan, A.P.; Dalpé, Y.; Lapointe, L.; Piché, Y. Soil pH-induced changes in root colonization, diversity, and reproduction of symbiotic arbuscular mycorrhizal fungi from healthy and declining maple forests. Can. J. For. Res. 2000, 30, 1543-1554. [CrossRef]

33. Liu, X.; Feng, Z.; Zhao, Z.; Zhu, H.; Yao, Q. Acidic soil inhibits the functionality of arbuscular mycorrhizal fungi by reducing arbuscule formation in tomato roots. Soil Sci. Plant Nutr. 2020, 66, 275-284. [CrossRef]

34. Sun, Y.; Zhang, X.; Wu, Z.; Hu, Y.; Wu, S.; Chen, B. The molecular diversity of arbuscular mycorrhizal fungi in the arsenic mining impacted sites in Hunan Province of China. J. Environ. Sci. (China) 2016, 39, 110-118. [CrossRef] [PubMed] 
35. Gosling, P.; Mead, A.; Proctor, M.; Hammond, J.P.; Bending, G.D. Contrasting arbuscular mycorrhizal communities colonizing different host plants show a similar response to a soil phosphorus concentration gradient. New Phytol. 2013, 198, 546-556. [CrossRef] [PubMed]

36. Olsson, P.A.; Bååth, E.; Jakobsen, I. Phosphorus effects on the mycelium and storage structures of an arbuscular mycorrhizal fungus as studied in the soil and roots by analysis of fatty acid signatures. Appl. Environ. Microbiol. 1997, 63, 3531-3538. [CrossRef] [PubMed]

37. Liu, J.; Sui, Y.; Yu, Z.; Shi, Y.; Chu, H.; Jin, J.; Liu, X.; Wang, G. Soil carbon content drives the biogeographical distribution of fungal communities in the black soil zone of northeast China. Soil Biol. Biochem. 2015, 83, 29-39. [CrossRef]

38. Luo, X.; He, X.; Luo, X.; Liu, Y.; Wang, J.; Dong, J. Soil organic carbon shapes AMF communities in soils and roots of Cynodon dactylon under anti-seasonal drying-wetting cycles. Diversity 2019, 11, 197. [CrossRef]

39. Stürmer, S.L.; Kemmelmeier, K.; Moreira, B.C.; Kasuya, M.C.M.; Pereira, G.M.D.; da Silva, K. Arbuscular mycorrhizal fungi (Glomeromycota) communities in tropical savannas of Roraima, Brazil. Mycol. Prog. 2018, 17, 1149-1159. [CrossRef]

40. Yang, H.; Yuan, Y.; Zhang, Q.; Tang, J.; Liu, Y.; Chen, X. Changes in soil organic carbon, total nitrogen, and abundance of arbuscular mycorrhizal fungi along a large-scale aridity gradient. Catena 2011, 87, 70-77. [CrossRef]

41. Cusack, D.F.; Silver, W.L.; Torn, M.S.; Burton, S.D.; Firestone, M.K. Changes in microbial community characteristics and soil organic matter with nitrogen additions in two tropical forests. Ecology 2011, 92, 621-632. [CrossRef]

42. Qiu, L.; Bi, Y.; Jiang, B.; Wang, Z.; Zhang, Y.; Zhakypbek, Y. Arbuscular mycorrhizal fungi ameliorate the chemical properties and enzyme activities of rhizosphere soil in reclaimed mining subsidence in northwestern China. J. Arid Land 2019, 11, 135-147. [CrossRef]

43. Zhang, Y.L.; Chen, L.J.; Chen, X.H.; Tan, M.L.; Duan, Z.H.; Wu, Z.J.; Li, X.J.; Fan, X.H. Response of soil enzyme activity to long-term restoration of desertified land. Catena 2015, 133, 64-70. [CrossRef]

44. Wright, S.F.; Upadhyaya, A. Extraction of an abundant and unusual protein from soil and comparison with hyphal protein of arbuscular mycorrhizal fungi. Soil Sci. 1996, 161, 575-586. [CrossRef]

45. Singh, A.K.; Rai, A.; Pandey, V.; Singh, N. Contribution of glomalin to dissolve organic carbon under different land uses and seasonality in dry tropics. J. Environ. Manag. 2017, 192, 142-149. [CrossRef] [PubMed]

46. Schindler, F.V.; Mercer, E.J.; Rice, J.A. Chemical characteristics of glomalin-related soil protein (GRSP) extracted from soils of varying organic matter content. Soil Biol. Biochem. 2007, 39, 320-329. [CrossRef]

47. Ma, M.; Ongena, M.; Wang, Q.; Guan, D.; Cao, F.; Jiang, X.; Li, J. Chronic fertilization of 37 years alters the phylogenetic structure of soil arbuscular mycorrhizal fungi in Chinese Mollisols. AMB Express 2018, 8, 57. [CrossRef] [PubMed]

48. Lu, X.; Lu, X.; Liao, Y. Effect of tillage treatment on the diversity of soil arbuscular mycorrhizal fungal and soil aggregate-associated carbon content. Front. Microbiol. 2018, 9, 2986. [CrossRef] 